A Delicate Aggression 
This page intentionally left blank 


\title{
A Delicate Aggression
}

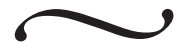

\author{
SAVAgery AND SuRvival in The \\ IOWA WRITERS' WORKSHOP
}

David O. Dowling 
Published with assistance from the Louis Stern

Memorial Fund.

Copyright (C) 2019 by Yale University.

All rights reserved.

This book may not be reproduced, in whole or in part, including illustrations, in any form (beyond that copying permitted by Sections I07 and 108 of the U.S. Copyright Law and except by reviewers for the public press), without written permission from the publishers.

Yale University Press books may be purchased in quantity

for educational, business, or promotional use. For

information, please e-mail sales.press@yale.edu (U.S. office) or sales@yaleup.co.uk (U.K. office).

Set in Scala type by IDS Infotech, Ltd.

Printed in the United States of America.

ISBN 978-0-300-21584-7 (hardcover : alk. paper)

Library of Congress Control Number: 2018950106

A catalogue record for this book is available from the British Library.

This paper meets the requirements of ANSI/NISO

Z39-48-1992 (Permanence of Paper).

I0 98765432 I 
For my faculty colleagues and students in the School of Journalism and Mass Communication at the University of Iowa 
This page intentionally left blank 